\title{
AGRTCULTURAL EDUCATION
}

\section{AS A FAOTOR IN DEVELOPING USEFUL MEN.}

\section{A N ADDRESS}

BY

PRED H. RANKIN,

Suparintandant Agrionitural Collage Extension, Univeralli of JHinais, Unbaza,

BEFORE THE

THIRTY-THIBD ANNOAL MEETING OF THE KANSAS STATK BOARD OF AGRTCULTURE,

TOPEK A, KAN., JANUARY 14, 1804.

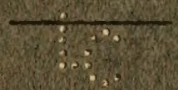

Atso,

CIROULAR OF INBORMATION, COLLIEGE OF AGRTOULTURE, UNIVERSIMY OF ILINOIS, URBANA, 1904 . 


\title{
AGRICULTURAL EDUCATION AS A FACTOR IN DEVELOPING USEFUL MEN.
}

\author{
AN ADDRESS BY FRED H. RANKIN, \\ Superintendent of Agricultural College Extension, \\ University of Illinois, at Urbana.
}

Deliverd before the Kansas State Board of Agriculture, at Topeka, January 14, 1934.

There are two things in this world which it easy to give and not so easy to to take. They are medicine and advice. From the healthy and robust appearance of the people in this audience, I do not believe you have much use for the former, and, besides, it is out of my line. As to advice, I believe that the average boy is in very much the same condition as the man who had goose for dinner every day for a week or two during his holiday visit, and about the last place he went to he was asked to say grace, and this is what he said:

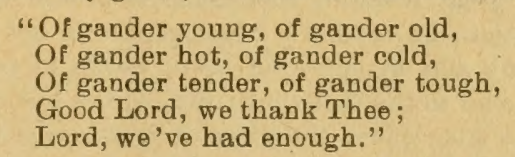

I have been asked to talk to you upon agricultural education as a factor in developing useful men. The speaker is one who sympathizes with young people, and is anxious to help them in an educational way, and realizes that most boys have manly aims and desires, and a strong purpose in mind to master some particular business, and, such being the case, will have an appetite for more schooling. The useful man in this world is the man who does his work well. Success in any vocation means doing your work well. Doing it well is all that is necessary to make the humblest occupation honorable. In the world's work, it matters little whether you raise corn or calves, peg shoes or write books, doing it well should be the true ambition of every worker.

There is an old saying, "Work is the engine which draws the car of success." While that is a very good motto, yet it could be improved upon. Hard work alone will not always bring success. Let me try to draw a word picture for you. Suppose we have standing upon the railroad-track a huge car labeled "success." In front of it stands a powerful locomotive which we will call "work." Is the picture complete? Is the train ready to move? No; you want a skilled engineer in the cab of that engine, with his hand upon the lever and his eye looking ahead; over him let us print in big letters the word "thought." Now we have a corrected motto which reads: "Thought is the skilled engineer who directs the engine, work, which draws the car of success." In short, it is well-directed labor that pays. Young men, we are living in an age when all kinds of successful business is thought out before it is worked out, which means the active exercise of both head and hand of those engaged in it. You know the world is full of fairly good workers. Excellent workers are scarce. It is not enough for a young man to try to do his best, but he must do the work given to him to do. Do it thoroughly and completely; best or no best, the work must be done and done satisfactorily. It is not a question of trying to do the best, but of actually doing 
the best. In short, to you young men going into the world's work, it is a case of "fish, cut bait, or get ashore."

Nothing reveals character so much as the way you do your work. A botched job shows a poor workman, while a good piece of work gives you the impression of strength and masterfulness. The fact that one young man may make a complete failure in his college work or in business, while another takes up the same work or the same business and makes a complete success of it, plainly indicates that there is something in men as well as instituticns and methods. The fact that there is more in the man than in the business is my reason for urging the young men in this audience to bend every energy in acquiring the right kind of ideals for their start in life.

The ability to do hard work, to think clearly and add to your manhood by honesty of purpose and integrity of your work will secure the confidence of all who have to do with you and you will not only win success in your college or life work, but, what is more, royally deserve it. Success never comes to any one by chance or luck. Chauncey M. Depew was once asked by a young man to give the secret of success, and replied: "My boy, there is no secret to it. It is just dig, dig, dig." Edison, being asked to give the definition of genius, replied: "Two per cent. is genius; ninety-eight per cent. is hard work." Upon another occasion, when the great inventor was asked if he did not believe that genius was simply inspiration, he replied. "No; genius is not inspiration, it is perspiration." It is my aim in speaking these words to you more thoroughly to awaken the young men to the fact that jouth comes but once, and the pathway of this life is only trodden once; therefore, it is all-important before taking up the chief work of life to be fitted for it as best you can, and make the very best out of the talent that nature has given you.

Often a person becomes lonely in the early days of his young manhood. $\mathrm{He}$ feels that the world was made before he had anything to say about it, and the places are all filled, and that he will have hard work to push his way into anything. He feels that he is almost an intruder and no one wants him. If any of you young men feel that way, let me set your mind at rest. The whole world is waiting, and waiting eagerly, for young men who "know how." The story is told of Emerson that he had a small flower-garden in which he took much pride. One day a young calf got in through the gate and the old gentleman had almost worn himself out trying to chase the intruder out the little gate. A servant girl was near by churning, and seeing the predicament and taking pity on the old philosopher, and, having a little milk upon her fingers, easily tolled the calf out the gate. The old man stood and watched the performance, and finally exclaimed: "Well, well; there is nothing like knowing how!"

My young friends, that is the secret; that is the surest road to success. The world wants men who know how; who are willing and have been trained to do things. If you have not found your place yet, consider whether you know how. Maybe you would better go where they do know bow, and work there for a time just to learn; then see if the way is not open. The speaker has spent his life, until three years ago, upon an Illinois farm, and believes there is no man who requires a broader and more scientific education than the young man who expects to make farming his vocation. The boy who takes a course in an agricultural college is vastly better fitted to win his way creditably and profitably than the one who learns by the hard knocks of experience alone.

I am often asked by young men: "Does the farm pay? Will it pay me as a life business?" I reply, Yes, if you have brains and intelligently use them. Why does every would-be lawyer or doctor spend two or three years in preparing 
to practice his profession? You say it is because he would starve to death without such training. Now, why is it, on the other hand, that no one has deemed it necessary to spend any time preparing for the life of a successful farmer? If one can make a living at farming without preparation, it argues well for the natural advantages of the business of farming. Now, how much more is it to the advantage of one who intelligently fits himself for farming, as does the lawyer, dector or business man for their respective vocations? If you would better your prospects and increase your income, why not grow the earliest and biggest crops in your neighborhood? Why not have the best herd of improved stock? Why not increase the fertility of your land and command your neighbors' respect by having the neatest and best-kept farm? My young friends, you are soon to face the problem of self-support, and I believe the majority of you would prefer to remain your own master and enjoy the independence of your own home, and it is the aspiration of every American boy to own his own land and spend money in improving and beautifying his home. Now, if you had an older friend who had made a pronounced success of farming, would it not be worth your while to spend some of your spare time with him learning what he knows about working the land, crop rotation, stock-feeding, system of farm management, and the like? Experience is a dear school. Can you afford to spend years in learning methode well known only a few miles removed from your home?

THE AGRICULTURAL COLLEGE THE FARM BOys' opPORTUNITY.

I want the farm boys of Kansas and other states of our Union to know more of the agricultural colleges and experiment stations. These colleges and stations are in close touch with practical farmers everywhere; so their ideas, instruction and advice are of general and not merely local value. Why not acquire these ideas and profit by them? Why not spend a few months or a year or two at the Agricultural College of your state. Reynolds, the celebrated artist, was once asked how to mix paints to produce his beautiful colors. He answered: "Mix them with brains." That is the way to make farming pay. Put brains into it. Consider if the "know how" and "reason why" of modern agriculture would not be worth studying. It is with the utmost confidence and from intimate personal knowledge that I say that agricultural education develops allaround, useful men. To the young men who expect to farm or have landed interests, the great advantage of an agricultural course is that it gives closer attention to farming problems. The charge has been made, and not without just grounds, that some of the higher educational work of the past used to run so largely to fine-spun theory that it lost sight of the practical; but in our agricultural and land-grant schools; such as you have at Manhattan, the courses offered are a happy combination of theory and practice, of study and of work. A young man not only studies the theory of things, but deals with the things themselves, in whatever department they are studied, until he becomes familiar with them. The courses are not only calculated to give him a better training, but in the wood shops, the forge room, the farm mechanics' laboratory, where hundreds of students are taught deftness of hand and skill with machinery; in the dairy manufacturing laboratory, where there is a complete equipment for creamery work; in the live-stock judging pavilion, where students handle hundreds of specimens of the different breeds of live stock - in any of these or other departments wherein a young man may take up work, he not only learns the theory of things, but gets practical work as well.

There is a plan about all this work; boys study theories and then actually carry them out. In short, the education which the college of agriculture will give to the boy is one by no means limited to languages or books, both of which 
are only expressions of what has been discovered. It would seek to acquaint the student with the facts and principles of the world and the ability to use them, taking the stand that a portion of the boy's education should be drawn out of the subject matter of his profession, and that it is a mistake to educate the boy without the slightest reference to matters he will handle when he comes to be a man. There is great interest from beginning to end of an agricultural-college course. While young men are growing deft and skilful with their hands, they are thinking clearer, and their desires and thirst for knowledge grow as the way to get it is pointed out to them. Not only are their hands and intellect trained, but, with the right kind of level-headed, sensible boys, their hearts grow more kindly and tolerant through social and intellectual intercourse as they rub up against each other, and they realize that they are building the best that can be received in this life, which is true, manly character.

I know that these colleges are doing good, conscientious work for young men, and $I$ am fortunate in being personally acquainted with many instructors in your own Agricultural College, and can assure you that these capable, earnest, conscientious men recognize that the high ends and crowns of success which await and invite their best skill is the building and growing into the daily life of these farm boys beauties of character as well as intellectual capability, in order to develop useful, all-round, capable men.

It is not alone the aim of agricultural-college training to pound a lot of knowledge into boys, which may or may not be of any practical use to them afterwards, but rather to fill them with a boundless enthusiasm and set before them high ideals, intellectual and moral. The agricultural colleges seek to train the students to be not only successful farmers but good men and intelligent citizens as well. In short, they seek to develop those qualities and aims which this world has no quotable market for and yet are of the highest demand and value in every market. It is the posssssion of these which promises to make the lives of the American farm boys companionable and wholesome while at their daily vocations, and potential in the affairs of the commonwealth, and finally worth taking with them to that undiscovered country from whence no traveler ever returns. I have the deepest sympathy for the unfortunates who pass through this world with only half equipment; these persons with no heart and no appreciation for poetry and art. No sadder sight is ever presented than is sometimes seen upon the farm, when the farmer is bound up both body and soul by thoughts and intents upon money-getting alone. To carry the efforts for developing land and accumulating property to the extreme of miserliness $d$ warfs and shrivels the development of true manhood even more than years can the aging body. The agricultural colleges believe this entirely uncalled for and unnecessary, and most foreign to those sunny and broadening influences which farm life invites.

And now a word of suggestion and encouragement to the boy who wants a college education. Perhaps you have been told that such an education would unfit you for the farm. I want to assure you that a real education which trains the eye to see, the hand to work and the mind to perceive the truth in all things will never unfit any man for the farm who is fit to be a farmer. Your success in getting an education which will be of practical value will depend primarily upon what sort of a boy you are, how hungry you are for knowledge, how willing you are to apply yourself, and on the natural strength of your mind. If you have not already gotten all you can from the schools near your home, let me urge you to devote the next year or two to mastering thoroughly the subjects taught in these schools. Get on good terms with your teachers and get their help. Send to the Agricultural College, at Manhattan, for a catalogue and suggestions as to 
books to read. They will be glad to help you. Keep your mind constantly at work in this direction. Remember, nothing can keep you from getting an education. We want you to have an education that will bring out the best that is in you; but remember you must get it yourself. No book, no teacher, no college instructor can educate you; you must educate yourself. Neither money, nor position, nor teacher, nor college can give development of mind and real education except you have a determination to appropriate these opportunities. "It is up to you."

If financial difficulties stand in the way, put your wits to work to gather enough money during the next year or two to give you a start in college. Work extra time and raise some crop. Do all the work yourself and pay rent for the land, if need be. Sell the crop and with the money buy pigs and sheep. Feed and sell these, and in this way start a fund to be used for books and to pay your way for a year or two at the Agricultural College.

I believe that most farm boys sincerely desire to better their prospects and be good, useful men. The trouble is that they sometimes do not know just how to go about it. To aid in starting them on the right track and to make their pathway plainer and easier is the object of the work which the Illinois College of Agriculture has recently taken up and called

AGRICULTURAL COLLEGE EXTENSION.

The work of this department has in view the bringing of the educational forces of the college in touch with the largest number of young persons possible living on Illinois farms, and inducing as many of them as possible to avail themselves of the advantages of higher education in agricultural and other lines. In the broad sense of the term, this work is a go-between for the department work of the college of agriculture and the young people of the state, in the way of encouraging the boys and girls to avail themselves of the training which the state courses afford. We feel that this is rendered necessary from the fact that young people of the farm have no very great encouragement toward higher educaton.

We have adopted the following leading features:

First.-Personal correspondence.

Second.-Attending farmers' institutes and personally visiting the homes of some of these young people.

Third.-Young people's experimental clubs.

Fourth.-Excursion parties to visit the University.

We have a growing list of the names of sereral thousand boys and girls, which names have been secured largely through the cooperation of friends of the college, and furnishes a good working-list upon which to base our efforts as indicated above: First, by personal correspondence, because it is an event in a boy's or girl's life to get a personal letter from some one who desires to help them become better and more useful citizens. We each recall that a few words of encouragement and sympathy helped us in early days, and we endezvor to put this spirit into our letters. Second, we enlist the interest and cooperation of some of the leading men in a county, preferably the superintendent of schools, and encourage them to organize these young people into so-called "young people's experimental clubs." A number of clubs have been organized in this way, ranging in membership from 30 to 300 . We supply these experimental-club workers with helpful literature. This season much interest was taken in the cultivation of Indian corn. Many institutes have offered prizes for the best corn raised by young people under eighteen years of age. Cooperating with the work of the institutes, we sent these young people leaflets containing information as to the cultivation of the corn, and furnished a record blank upon which they re- 
ported to us. In addition, some simple experiments were outlined, such as the effect of root pruning, counting the number of barren stalks, time of pollenization, etc.

The results of these observations are sent in to us as a report from these young people, who begin to observe more closely how corn grows. A large number of observations as to smut in oat-fields have been sent to us upop blanks which we supplied. Early in the summer we sent out a suggestive form for a weather chart and information as to how to make a simple rain-gauge. The circular also contained a number of suggeslive methods of observation work to be taken up during vacation. Its aim was to make the boys and girls observe the every-day things; to find untold pleasure in the undiscovered beauties of nature, as well as to give closer attention to farming problems. When we sent out a circular asking for data as regards farm machinery which had been left $\theta x$. posed to the rain and sun, several reports came in filled out, and with this kind of a foot-note: "When your blank came we had a plow or hay-rake out in the field, but it is now sheltered." These boys had evidently been awakened to new facts.

We are just now sending out a leaflet intended for the girls as well as the boys, making a special study of what pure air and proper ventilation mean to the home and dwelling-rooms.

As an outgrowth of the experimental work supplied to these clubs of the young people, and the young people individually, they become interested in this work and desire to visit the college of agriculture and become better acquainted. We have had excursion parties from some eighteen different counties throughout the state, ranging in number from 60 to 640 persons. Rates were secured from the railroad companies, and when the party came they were personally conducted over the university farms and through the buildings, and we served them with a simple lunch one of the days while here. Through the medium of these excursions, many parents are encouraged to come here and bring their children, and much good is thus accomplished when they see the great opportunity presented to them at their agricultural college. Who can tell the thoughts that run through the minds of these young people when they first go through the college halls? I know that as an outgrowth of these excursions many young people have expressed a determination to complete their high-school work and prepare themselves that they may come and spend one or more yeare at the university. They return to their homes having a new incentive for diligent work, that they may in the near future have a part in the great university life. As a result which I believe is largely attributable to this work, the boys and girls come to the college of agriculture better prepared to take up the work than they formerly did. This was quite evident on the last registration day. In short, this work gives an introduction, as it were, and enables the young person to come more gracefully into university life and the requirements and demands which are made upon him. Our idea is to make it a personal matter in this work with the boys and girls and to get into closer touch with as many as we can and study their needs and inclinations; in the main, we are trying to use rifle instead of shot-gun methods, and get directly after the boys and girls, and follow them up both with literature and personal letters.

We keep a card-index system, entering the name of each young person; his post-office and county; whatever he is especially interested in; number of brothers and sisters he has; their age; occupation of parents; size of farm they live upon; record of literature sent; and letters sent and received.

We attend a number of institutes in the state, and, if going to a meeting, for instance, in Adams county, we will, a couple of weeks before the meeting, send 
letters to all the young people in that county whose names we have on our list, telling them that a representative of the college will be present at the meeting. Then draw their attention in a personal manner to that special feature of the program in which we know from the eards they are especially interested. Then, upon going to the meeting with these carde in our pocket, we can study out and know the names and something in detail of the particular young people we are going to meet. Such is, in brief, an outline of the nature of the work we are doing in the way of agricultural college extension.

Briefly, the results are as follows:

First.-An interest in agriculture is awakened early in life, as most of these people are but twelve to fourteen years of age.

Second.-An increased number of students in the college of agriculture, seventy-five more having registered this year than did a year ago.

Third.-Better preparation of these students.

Fourth.-A more general appreciation among young people on the farm of the advantages of higher education in all lines, resulting in an increased attendance in all courses.

Fifth.-A wider and more intelligent conception of what the college of agriculture is doing and of its needs.

Much of this work is of such a nature that its results cannot be tabulated or expressed in words and figures. It has already given fruit along the lines above mentioned, and the belief is cherished that what has been accomplished is but a fraction of what is bound to follow the cumulative effect of this line of work. We believe there is certainly a field for this kind of work, and the good results of this direct personal effort are bound to be felt in quickening the aspirations of boys and girls. We are endeavoring to carry the thought of culture and higher education into the farm homes and to give these young people a glimpse of all the great things that agricultural prosperity means, and cause them to seek out and inquire more earnestly for those thinge which will contribute most effectually and most directly to agricultural prosperity. We endeavor to bring no spirit of bigotry or partizanship into this work. We believe that every young person should follow the lead of his inclinations and adaptability. Every farm boy is no more fitted to become a farmer than every boy who is born near a corner drugstore is fitted to become a druggist; but we believe in encouraging young men who expect to farm to be good farmers and fit themselves for their business, just as you encourage their brothers who take up professional life. Thus shall be developed a class of men true and tolerant and useful in the home and potential in public affairs.

The prime requisite for all this work is to be thoroughly in earnest and heartily in sympathy with the work. If a young person feels that some one sympathizes with him and really does care whether or not he makes a man of himself, he is bound to be more or less influenced and guided by such an one, and sometimes a letter or a half-hour's conversation contains the destiny of a life. I will give one concrete instance of this: Last winter I went into a farm home near Bloomington, Ill., where were four boys, the oldest of whom was twenty years old. He was a senior in the high school and expected to take a course in electrical engineering. His brother who was younger had been out of school for two years. He expected to follow farming, and said he did not believe higher education would be of any practical value to him. The family knew little or nothing concerning the work of the college of agriculture, although well informed upon general topics. We lighted a lantern and went out to the corn-crib and got some corn, which we scored for the boys; told them how we judged stock; and of the 
work in farm machinery, wood shops, the forge room. They were interested, and we sat up until midnight pointing out the difference between an educated and an uneducated man. The next morning the father thanked me for my visit and promised to bring the two older boys over to visit the college. They came during the summer vacation. I spent the day showing them over the grounds and through the buildings. As a result, the older boy came this fall to enter the engineering school and his brother is now with us in the college of agriculture, and expects to remain not less than two years. And then there are two younger boys in that family who will be influenced by that evening's visit. Did it pay?

That there is room for and need of the state adopting this policy in her education of the young people of the farms to develop her agricultural productivities, is best answered by referring to the hundreds of letters which these young people write and the buoyant enthusiasm with which they enter into the spirit of this work.

BUILDING FIBER INTO AMERICAN LIFE.

Ladies and gentlemen, agricultural education is building the best fiber into the structure of American life, and is destined to bear still nobler fruit. Remember your Agricultural College, at Manhattan, will not educate these boys away from their Kansas farm homes, but what it must do and will do is to educate them in their surroundings. The training they receive there will not only increase their earning capacity, but will so fit them for the work of life that they will make the farm homes of this resourceful state the most attractive places on earth. Twenty yeare hence the farm boys now before me will be filling your offices and will mainly control the business of the state and be potential factors in our national life. I plead with you to foster and give financial aid to your Agricultural College, for the education it offers to your boys will give them such soundness of judgment on all questions that the name "farmer" will no longer mean a mere tiller of the soil, but will be a badge of distinction and a mark of honor. The great need of our agricultural commonwealth is more first-class young farmers to take second-and third-rate farms and make them first class. Where is there more available material for our future farmers than is now presented by Kansas boys? To speak some little word which will aid in winning these Kansas boys to a life of devoted interest to your farming future is my mission at this meeting. My young friends, do not be misled by the fact that perchance many of our fathers succeeded well in their life-work with but little school or college training. Remember, they lived in different times, and that these opportunities were not available to them. There is a smaller sphere for the uneducated man of every decade, and a diminishing possibility of success for the man who does not read and think. The reading man is in the saddle. The thinking man is guiding our national destinies.

The latch-string of your college hangs out, and there is not a young man in the state who cannot take an agricultural course, provided he only makes up his mind to that end. Gentlemen, the Kansas farmer who uses fifty dollars in sending his son to the Agricultural College, at Manhattan, is making a far better investment than in putting $\$ 500$ into barns or alfalfa-fields.

AGRICULTURE IN THE RURAL SCHOOLS.

I take it that you have all agreed with me in the general statement that the boy who farms should be educated. But the speaker takes the ground that the rural schools, which are so often the farmers' preparatory and finishing schools, should consider more fully the environment and probable future life of the pupils, and that, while the boys are in leading-strings, so to speak, there should be some recognition of the life they expect to follow. 
Our district schools recruit the academy, the college, and the university, and they in turn have been recruiting every profession under the sun except farming. A majority of the workers in this state are engaged in agriculture. The environments of your children are rural. Gentlemen, the dominant question of this meeting is not expansion in acres or in national possessions; rather, it is the expansion of the brain, the skill and the judgment of the farm boys in Kansas. Am I asking too much when I plead for the cooperation of your rural teachers, that their instruction be shaped somewhat in harmony with the calling which a majority of their pupils must eventually engago in, and thus make their influence at least correlative with the work of the Agricultural College of your state? All about our school buildings, in the fields and forests, are many objects of intense interest to every human being, but $I$ fear that tho averago school-teacher of to day is as indifferent to these object-lessons as though his school building was in the heart of a great city. Why cannot these country school children be instructed along lines which will enable them to derelop the powers of observation of the natural objects about them? A growing corn plant or the root develop. ment of the clover plant, when properly explained, are certainly objects of tho keenest interest to children, whether they live in the city or country.

I do not believe that our rural schools can teach practical farming, but they can teach many things about crops, soils, animals, feeding. stuffs, trees, etc., which will help to make more practical farmers, and help to make all who live in the country have a keener appreciation of rural life and its wonderful opportunities.

There are a'few scientific terms that should be as familiar to the farmer boy as the multiplication table - such as "protein," "carbohydrates"; or the essential elements of soil fertility, as "nitrogen," "phosphorus," "potash," etc. Let me ask you if they are any harder to understand or remember or use than such "shop" words and phrases as "minuend," "subtrahend," "greatest common divisor," "aliquot parts," "conjunctive adverbs," etc.-words which are rarely, if ever, spoken outside of the schoolroom, and yet which are drilled into the country boys year after year, as though they were vital to their very existence.

I believe that it is as practicable to teach elementary agriculture or nature study in our country schools as it is to teach history or physiology.

To the older ones in this audience I would say, were we privileged to return to our childhood days, could we not, with the knowledge which the years have brought, give a more certain trend to the acts of that period? Yet to you, as friends, teachers, or parents, there comes the opportunity to place yourselves, in a measure, beside this later-day child, the farm boy, and, as a child with him, lead him to that higher plane of which true manhood is the summit.

THE MEANING OF THIS-THE HOME.

And now, if all that I have said means anything, it is that your farm boys should not live for the sole purpose of raising corn to feed hogs to buy land to raise more corn to feed more hogs, and so on in this ceaseless circle until the Almighty shall put a stop to such hoggish proceedings. No, there is something else to be thought of. This life should not all be spent in mere money-getting health is better than wealth. Love, friendship and family affections are worth more than gold. Of that young man who makes farming honorable as well as profitable, who demonstrates that farm life promotes mental and moral culture and is favorable to the exercise of all those qualities that make life pure and noble, who surrounds his home with objects of attraction and beauty, and who shows to the world his faith in and love of his calling - of such a character, I 
say, nature may be proud to stand up before the whole world and say, "This is a man."

We Americans lore our homes and we want to make them into the best homes in the world. Not many years ago a ship left one of our Atlantic ports with no cargo, no passengers, and sailed across the sea until it reached a wharf where it waited for its only cargo. The cargo was a long pine box brought on to the ship; then silently the prow was turned towards home, and across the sea came the ship day by day, until it reached our own shore, and then all over this land thero were guns booming and flags at half-mast and bells tolling, and all because the dead body of one man, a simple American citizen, had been brought back to this land for burial. And that dead body was so honored because that man-John Howard Payne-had written the words that we sing and call, "Home, Sweet Home." We are all Americans, and Americans know that, in order to make this nation strong and earnest and wise and truo, homes must be built up. We must teach and educate these farm boys that to be strong, clean, earnest, true men is to find the best heritage that can be given to an American. Having the heart to will, the brain to plan, and the hand to do, means the best of attainment.

In conclusion, there is a little simile I will leave with you: Way up in the Swiss mountains there is a small lake that has two outlets; one drop of water falling from the clouds finds an outlet to the north, follows the wide and winding river Rhine, past the historic cities of Germany, enters the North sea, flows along the frigid shores of Denmark into the Arctic ocean, and is finally locked up and imprisoned in some huge iceberg. Another drop from the same cloud, joining innumerable companions, finds an outlet to the south, and forms the river Rhone, flows through the fertile valleys of France, and mingles with the blue waters of the Mediterranean sea, past the historic shores of Italy, and among the storied isles of Greece, bearing the burdens of commerce, and the while smiling in the gladsome sunshine.

How widely different the fate of these two raindrops from the same cloud; yet not less dissimilar are the lives of two boys. One is careless, idle, indolent, drifting from bad to worse; making of life a complete failure. The other is industrious, ambitious, painstaking; doing his tasks thoroughly; climbing higher and higher the ladder of fame, until success finally crowns his efforts.

Ladies and gentlemen, there are certain points in intellectual development and morals, certain ideals and ambitions, most of which are acquired in the boy's school life, that determine the groove down which his life shall run through time to an endless eternity.

And now I am done. I have taxed your patience, but it has been a pleasure to talk to you, for you have helped me by being good listeners. I feel as though each one of you was a personal friend to me. You have been so kind and cordial to a stranger who came among you.

I believe that most of you young men will succeed:

"We all believe in Kansas; she's the state,

With all the elements to make her great-

Young men, high hopes, proud dreams; 't is yours to see

Your state succeed to what a state should be."

Remember though, that the greatest success lies not in the mere making of money or making a great stir in the world, but that it consists primarily in the building up around this personality which encloses the body a true manly character. In that alone come peace and happiness. Remember that your acts are immortal through their effects on the world and the lives of others. Try to live so that others will be lifted up by you. 


\title{
COLLEGE OF AGRICULTURE AND AGRICLLTLRAL EXPERIMENT STATION, UNIVERSITY OF ILLINOIS.
}

\author{
E. DaVenport, Dean and Director.
}

\section{HEADS OF DEPARTHENTS.}

T. J. BURRILL

D. McINTOSH. D. McINTOSH........... Veterinary Science.

E. DAVENPORT
Botany. .. Thremmatology. FRED H. RANKIN
J. C. BLAIR. .

Animal Husbandry.

ISABEL BEVIER ........ Household Science.

\section{HORTICULTURE.}

J. C. BLAIR.

Professor of Horticultare.

T. J. BURRILL.

Forestry.

J. W. LLOYD

Olericulture.

C. S. CRANDALL Pomology.

A. C. BEAL Floriculture.

AGRONOMY AND CHEMISTRY.

C. G. HOPKINS. Professor of Agronomy.

L. H. SMITH Plant-breeding.

F. R. CRANE Farm Mechanics.

J. G. MOSIER Soil Physics.

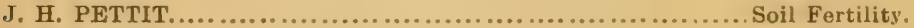

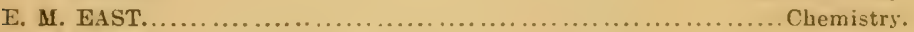

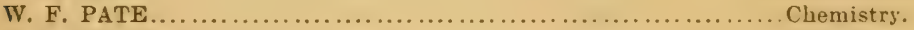

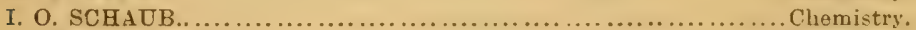

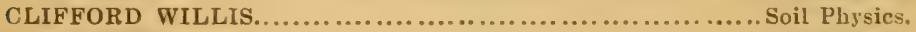

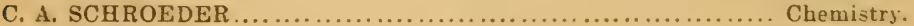

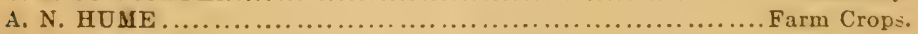

DAIRY HUSBANDRY.

W: J. FRASER..........................................

J. W. HART........................................ Dairy Manufactures.

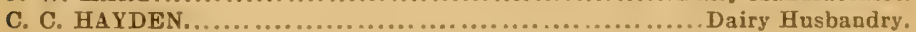

H. A. HOPPER .................................................... Husbandry.

FIELD-WORK - NORTHERN ILLINOIS.

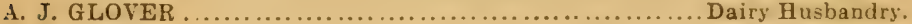

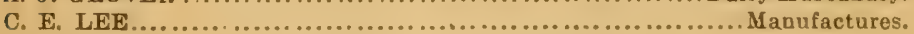

ANIMAL HUSBANDRY.

HERBERT W. MUMFORD

Professor of Animal Husbandry.

L. D. HALL....

Instructor in Beef Cattle.

R. C. OBRECHT Instructor and Investigator in Horses.

IV. DIETEICH. Instructor and Investigator in Swine.

E. S. GOOD Assistant in Animal Husbandry.

DEPARTMENT OF HOUSEHOLD SCIENCE.

ISABEL BEVIER.

Professor of Household Science.

GERTRUDE CLARK SOBER Instructor in Household Science. 


\section{CIRCULAR OF TNFORMATION.}

IIRCH, 1904 .

\section{COLIEGE OF AGRICULTURE, \\ UNIVERSITY OF ILLINOIS, URBANA.}

WHO ARE ADMITTED.

Anybody who reads and speaks English and is sixteen years of age may be admitted to the College of Agriculture.

CONDITIONS OF ADMISSION.

For graduates of accredited high schools and for students eighteen years of age there are no conditions, unless the person is deficient in English, when, if under twenty-one, he will be assigned to the Academy for that subject. If between sixteen and eighteen years of age and not a high-school graduate, he will take one-half his work in the Academy and the other half may be taken in agriculture.

\footnotetext{
WHAT ADMISSION MEANS.
}

When a person is admitted under any of these plans, it means that all studies of the University as well as of the College of Agriculture are open to him in the same way as to any other University student.'

It means, too, that whether his stay be long or short he will obtain university creatit for whatever he does, whether it be much or little, and this credit can be applied to graduation at any time the student may desire.

WḦAT CAN BE STUDIED.

Everything taught in the University is open to a student admitted to this College. The system is elective, and the student chooses his own work, under guidance and advice. The College of Agriculture alone offers over 100 courses, some elementary, others exceedingly difficult. Naturally the student would take the more elementary courses first.

WHAT CAN BE STUDIED AT ONCE.

After the student has been on the grounds he will be able to make his selection intelligently, but for his first guidance the list on the following page is printed. It contains nothing that the student may not take the first year, and is thus a good list to choose from on entering. If he expects to stay a year or more, he would do well to choose chemistry as one of his studies. Under the United States law, all students take military drill.

HOW MUCH CAN THE STUDENT TAKE.

After each study in the list is a number. A student may ordinarily take studies adding up to eighteen in each semester, or thirty-six in one year. Exceptional students may take a little more.

WHO OUGHT TO GO.

Everybody who expects to live on the farm should go to this College, if only for a brief period.

WHEN SHOULD HE COME.

At any time when it is possible, but the best time is at the opening of the year. A good time is at the opening of any half semester, when new studies are started. 
HOW LONG SHOULD HE STAY.

As long as circumstances permit. He should take a college course and graduate, if possible, but he should come, if only for a half semester or even a month.

SCHOLARSHIPS.

Three kinds of scholarships are open to students in this college :

1. State scholarships, one for each county, to be had on competitive examination at the county court-house of each county the first Saturday in June.

2. Farmers' institute scholarships, one for each county (ten for Cook and Lake), to be had without examination, upon recommendation of the State Farmers' Institute.

3. Household science scholarships; one for each county (ten for Cook and Lake), to be had without examination, upon recommendation of the county associations of domestic science.

EXPENSES.

Scholarship students pay no fees of any kind to the University except for materials consumed in the laboratories and for instruction in the Academy, if such is necessary ( $t$ wo dollars per subject per semester).

Special students not holding scholarships pay twelve dollars per semester for incidentals and seven and one-half dollars tuition.

IT IS A GOOD PLACE TO GO.

The elective system is in operation, and the student gets what he wants and is not required to take what he does not need. Whother his stay is long or short, whatever he does is thoroughly done, and he gets credit for what he accomplishes.

Many interesting experiments are in operation and plainly to be seen by the student. There is a staff of twenty-five teachers. The laboratory system is used, whereby the student does the work himself under the personal direction of the specialist. The College and Station own extensive laboratories, well equipped, from 200 to 300 head of cattle, with horses, sheep and swine in proportion, extensive plantings in horticulture, and a complete agricultural and general library.

Many important meetings are held at the College every year, and a two weeks' convention is held each winter, in January, attended by leading farmers from all over the state, and addressed by men prominent in agriculture. This is known as the Corn Growers' and Stockmen's Convention and the Housekeepers' Conference. The first two hours of the morning and all of the evening are given to the convention. During the remainder of the day classes are conducted in stock judging, corn-judging, farm mochanics, butter-making, and household science.

NO DISTINCTIONS AMONG STUDENTS.

Some institutions discriminate againet agricultural students. It is not so here. The University of Illinois is a democratic institution, and all classes of students are welcome-engineering aud agricultural studonts, scientists, literaries, and law, all mix without distinction. Everybody is happy and everybody is busy at the University of Illinois.

OPPORTUNITIES EXCEPTIONAL.

It is generally conceded that this College offers courses in soils, crops, animal husbandry and horticulture second to no other institution. It is not so generally known that four men devote their ontire time to dairy husbandry, and that butter-making is in progress throughout the year, offering unusual opportunities to students of dairying at any time they may find it convenient to come.

To learn all that the University is doing in agriculture, write for catalog.

Address W. L. Pillsbury, Registrar, E. Davenport, Dean, or Fred H. Rankin, Superintendent College Extension, Urbana, Illinois. 


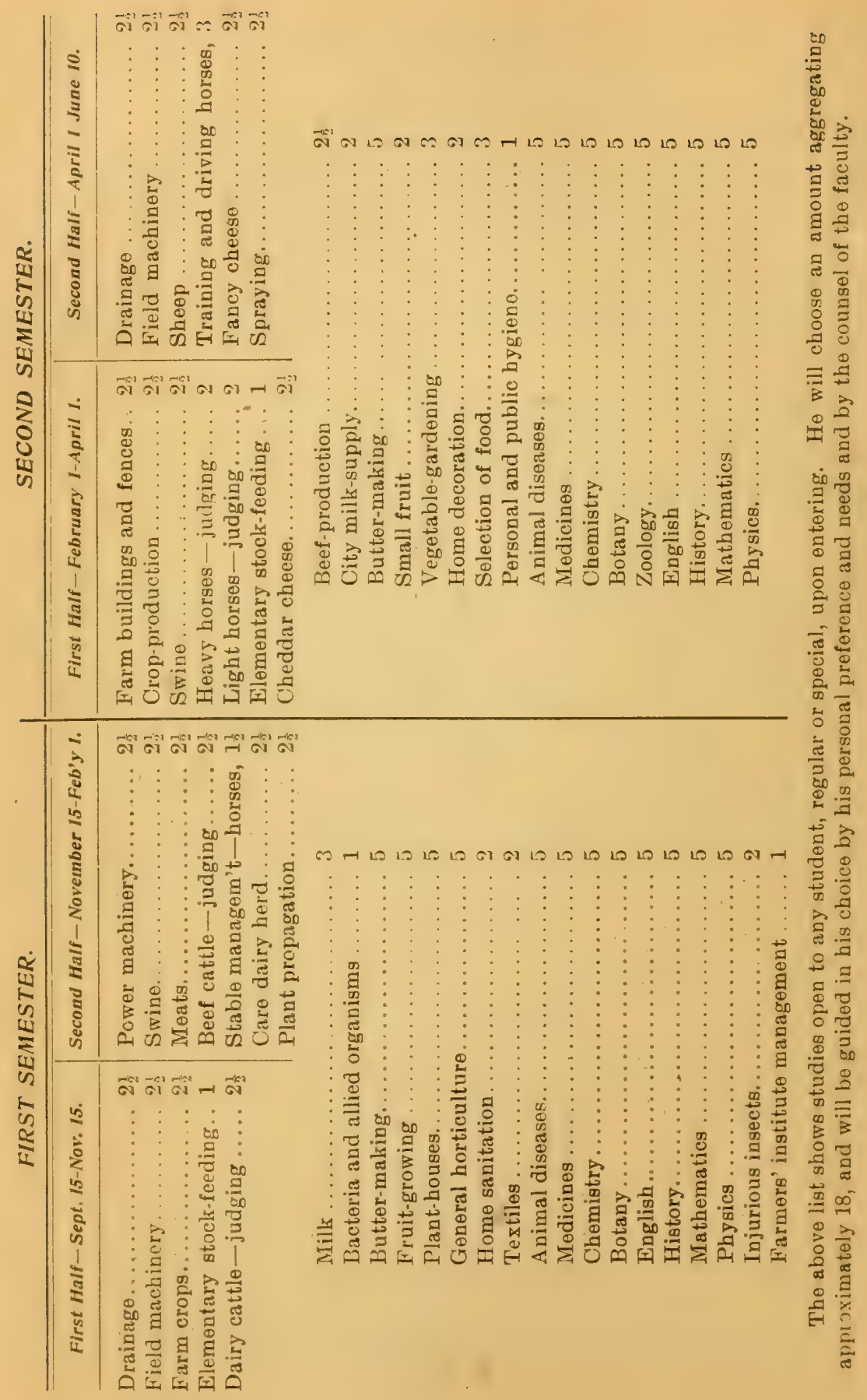




\section{A WORD TO THE FARM BOY.}

You are growing restless on the farm. The writer knows just how you feel, for he has traveled after the plow many a weary day thinking the thoughts that you are thinking now. You know that there is a great outside world which you desire to enter and which can only be entered satisfactorily through the portals of an education. You believe that an education would be worth more to you than your father's farm, and would give that farm, if you had it, for that education. We sympathize with you, for that was our dream for long years by day and by night. We approve of the feeling that inspires it. We would like to see every bright boy have an education, but we would not like, unless you are particularly qualified for it, to see you secure an education which would land you in one of what are called professions.

The country is full of lawyers, the majority of them briefless and obliged to get a living in real estate, insurance, or some other business quite apart from the law. They have been driven out practically from the profession for which they spent thousands of dollars and years of time to acquire fitness. The same may be said of doctors and preachers. If you are qualified for it by nature and grace, there is no profession more honorable, nor, in fact, so honorable, as that of a minister of the Gospel, but, unfortunately, many a man who has had in him the making of a good farmer has been spoiled by becoming a poor preacher.

We know of but one branch of education that has a certain, definite job waiting for the graduate when he gets his diploma, and that is an agricultural education. Every other profession is overcrowded. In this the supply is not equal to the demand, and will not be in the next twenty years. The farm boy who, having learned the practical part of farming, having familiarized himself with the machinery and become qualified to handle farm animals as they are handled on his father's farm, will take a thorough course at the Agricultural College will be just the kind of a man, provided, always, he has the brains and the grit, that the world is looking for to-day. You may devote yourself to horticulture, to stock-breeding, to dairying, to butter-making, to cheese-making, or to cattlefeeding, and, if you have the stuff in you, you will find a job, and a good-paying one at that, waiting for you at the end of the course. The colleges and experiment stations will require the services of a great many educated young farmers. It will not be many years before every line of railroad in the West will have an industrial department, which no one ean run who does not combine the theoretical with the practical. A railroad official told us the other day that they needed a man of this kind, and we pointed out the kind of man required, he said: "Why, that man would cost $\$ 5000$ a year." The Department of Agriculture needs more than anything else this kind of men, and boys without eapital, who will qualify themselves for this kind of work, will not need to wait ten or twelve years before they see a living clearly ahead of them.

As the years go on, it will become more apparent that the man who will farm successfully must have the "know how," which he can gain only by long experience and reading at home, or by an education plus experience and reading. Four years at college, or even two years, will be worth to you twenty years of farm life without it. Therefore, we say to the young man, not "Go West," but "Go to college if you possibly can. Go to an agricultural college."

Don't start out to be a pure scientist; you want a broader education than that. It will pay you if you go back to run your father's farm. It will pay you if you buy a farm of your own. If you are not able to do this, somebody who has a farm will need you. The oil-meal folks were not long since looking for a young man to act as their agent who knew how to feed cattle and how to compound rations of which oil-meal is a part. Every line of business that has to do with farmers greatly prefers a man who not only knows how farming is done, but why it is done, and hence is in touch with the farmer.

Don't go West, young man; don't go to the city; go to the Agricultural College, and to the agricultural end of that college. This would be our advice to you if we never wrote another line. It would have been worth fifteen years of life to the editor of this paper if he had had the opportunity at your age to fallow the line which he maps out to you.-Dr. Henry Wallace. 



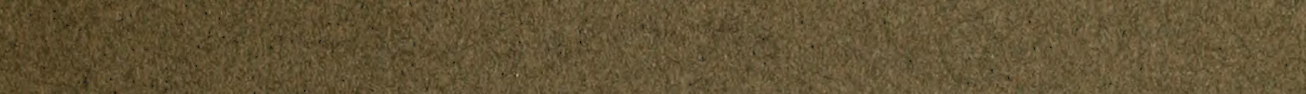
(2. S.

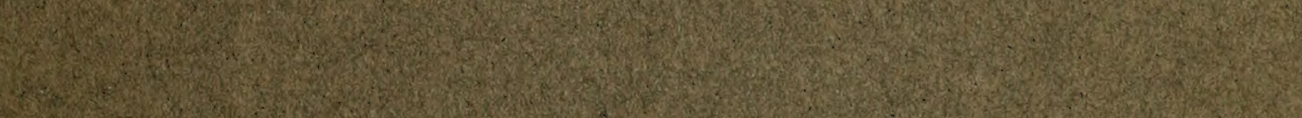

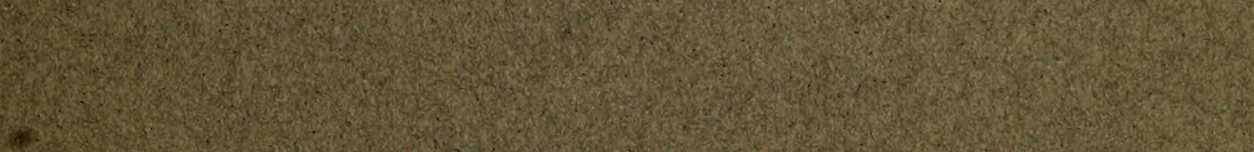

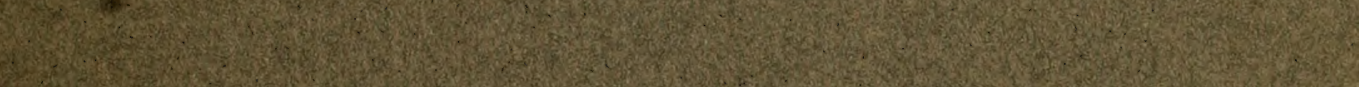

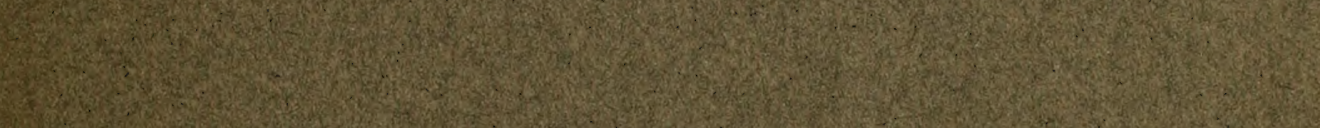

C.

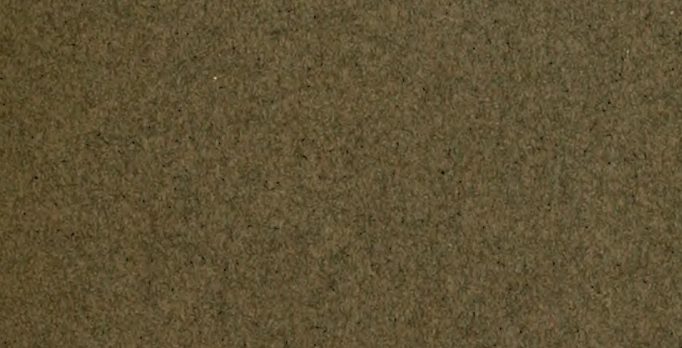

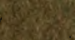

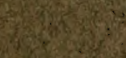

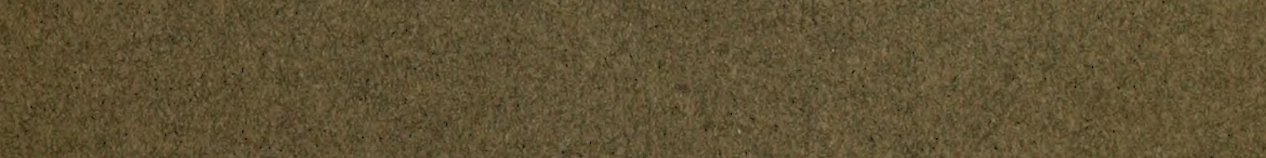

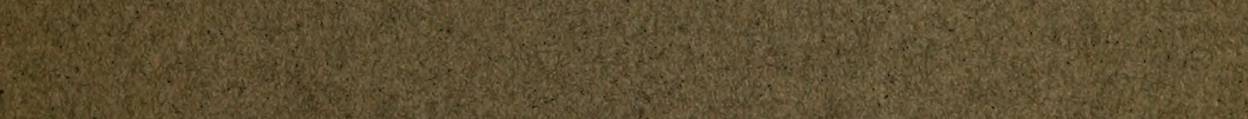
C. (1) (2). (it)

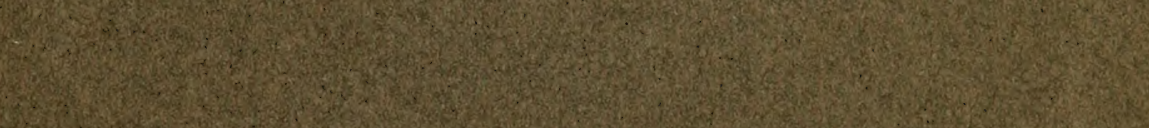

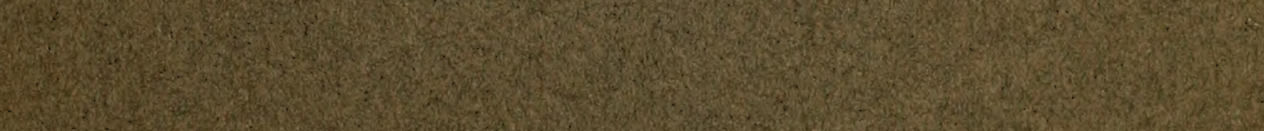

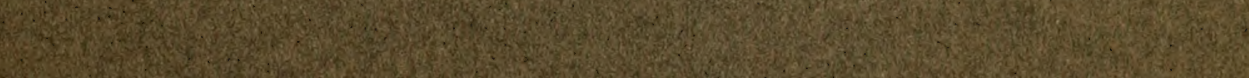

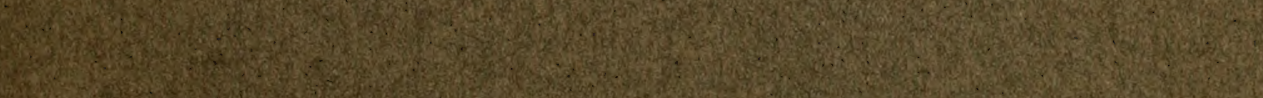


LIBRARY OF CONGRESS

|||||||||||||||||||||||||||||||||||||||||||||

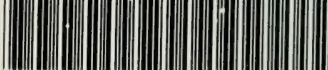

( 002782 281

0 0027822812 